\title{
RESENHA: Literatura afro-brasileira: 100 autores do século XVIII ao XX, e Literatura afro-brasileira: abordagens na sala de aula.
}

\author{
DUARTE, Eduardo de Assis (coord.). Literatura afro-brasileira: 100 autores do século
} XVIII ao XX. Rio de Janeiro, Pallas, 2014.

DUARTE, Eduardo de Assis (coord.). Literatura afro-brasileira: abordagens na sala de aula. Rio de Janeiro, Pallas, 2014.

\section{Mauricio Silva ${ }^{1}$}

Impulsionado pela aprovação, há mais de dez anos, da lei 10.639 e pela visibilidade cada vez maior dos movimentos de valorização da matriz africana da cultura brasileira, os estudos acerca da produção literária afro-brasileira tem ganho, nos últimos anos, importância cada vez maior. É o que demonstra - entre outros exemplos - a recente publicação dos livros Literatura afrobrasileira: 100 autores do século XVIII ao XX e Literatura afro-brasileira: abordagens na sala de aula, ambos organizados pelo professor e pesquisador Eduardo de Assis Duarte.

Ligado à Universidade Federal de Minas Gerais, o autor teve a colaboração de vários outros pesquisadores, num verdadeiro trabalho em conjunto, que se reflete no amplo levantamento de obra e autores, bem como de práticas pedagógicas, presentes nos dois volumes. Com efeito, pode-se considerar que, a rigor, se trata de um livro escrito em dois volumes, tamanha é a interação entre eles: um dedicado às obras e autores, bem como à uma discussão introdutória do conceito de literatura afro-brasileira; outro dedicado a metodologias voltadas à abordagem da literatura afrobrasileira na sala de aula dos ensinos fundamental e médio.

No primeiro volume, o autor começa fazendo um questionamento sobre a questão da cor da literatura, lembrando que esse conceito remete à identidade e valores que se fazem presentes na linguagem que constrói um texto: "a literatura afro-brasileira se afirma como expressão de um lugar discursivo construído pela visão de mundo historicamente identificada à trajetória vivida entre nós por africanos escravizados e seus descendentes" (p. 11). Nesse sentido, completa, quando o

1 Professor Doutor do Programa de Mestrado e Doutorado em Educação, na Universidade Nove de Julho (São Paulo). E-mail: maurisil@gmail.com . 
prefixo "afro" é acrescentado ao escritor negro brasileiro, ele ganha densidade crítica (tal escritor torna-se afroidentificado), inscrevendo o negro de outra maneira no cânone literário brasileiro.

Para o autor, a partir dos anos 1980, a literatura brasileira assiste a uma espécie de "esgotamento e superação do projeto modernista" (p. 11), resultando numa diversidade muito grande de projetos e na afirmação das minorias. No que compete às minorias raciais, Eduardo Assis lembra que grupos de escritores negros se organizam, principalmente a partir da década de 1970, em coletivos (Gens, na Bahia; Negrícia, no Rio de Janeiro; Palmares, em Porto Alegre; Quilombhoje, em São Paulo), atravessando gerações.

Defendendo a existência de uma literatura afro-brasileira múltipla e diversa, o autor aponta também para a necessidade de construção de novos "operadores teóricos" (p. 20), a fim de dar conta dessa produção. Assim, procura fazer, nesse contexto, a distinção entre uma literatura negra, ligada à luta contra o racismo, de tradição militante, com uma linguagem que denuncia o estereótipo, mas também padecendo de uma heterogeneidade que permite incorporar até mesmo uma produção ligada ao negrismo descomprometido e exótico; e uma literatura afro-brasileira, que remete ao "tenso processo de mescla cultural" (p. 25) próprio da nação brasileira, supondo um sujeito de enunciação próprio e um ponto de vista específico: "nesse contexto, vejo no conceito de literatura afro-brasileira uma formulação mais elástica (e mais produtiva), a abarcar tanto a assunção explícita de um sujeito étnico - que se faz presente numa série que vai de Luiz Gama a Cuti, passando pelo 'negro ou mulato, como queiram', de Lima Barreto - quanto o dissimulado lugar de enunciação que Caldas Barbosa, Machado, Firmina, Cruz e Souza, Patrocínio, Paula Brito, Gonçalves Crespo e tantos mais. Por isso mesmo, inscreve-se como um operador capacitado a abarcar melhor, por sua amplitude necessariamente compósita, as várias tendências existentes na demarcação discursiva do campo identitário afrodescendente em sua expressão literária" (p. 27).

Desse modo, Eduardo Assis propõe a presença de alguns identificadores para a consideração de uma obra e um autor como próprios da literatura afro-brasileira: "uma voz autoral afrodescendente, explícita ou não no discurso; temas afro-brasileiros; construções linguísticas marcadas por uma afro-brasilidade de tom, ritmo, sintaxe ou sentido; um projeto de transitividade discursiva, explícito ou não, com vistas ao universo recepcional; mas, sobretudo, um ponto de vista ou lugar de enunciação política e culturalmente identificado à afrodescendência, como fim e começo" (p. 29).

Especificando melhor cada um desses aspectos, o autor define o tema afro-brasileiro como "um dos fatores que ajudam a configurar o pertencimento de um texto à literatura afro- 
brasileira" (p. 29), podendo ser desde a história do povo negro na diáspora brasileira até a denúncia da escravidão, passando pela tematização de heróis como Zumbi dos Palmares, indo num sentido contrário ao apagamento da história e cultura dos negros. Outros elementos dessa temática podem ser as tradições culturais e religiosas trazidas para o Novo Mundo, a miséria e exclusão dos afrodescendentes no mundo atual etc. Sem ser uma camisa de força, a temática afro-brasileira, completa ele, não deve ser considerada isoladamente, mas na sua interação com os demais fatores.

Sobre a voz autoral, a questão é bastante complexa, não se devendo compreender a autoria como um dado "exterior" (há autores identificados fenotipicamente com a questão do negro, como há autores que, embora negros, não reivindicam essa condição para si nem a incluem em seu projeto literário, havendo ainda autores brancos que tratam de assuntos relativos aos negros pela ótica do negrismo), mas "como uma constante discursiva integrada à materialidade da construção literária" (p. 32). Torna-se relevante, nesse sentido, a interação entre literatura e experiência de vida: "desse modo, a autoria há de estar conjugada intimamente ao ponto de vista. Literatura é discursividade, e a cor da pele será importante enquanto tradução textual de uma história própria ou coletiva" (p. 34).

Um dos aspectos que o autor reputa como dos mais importantes, o ponto de vista, indica "a visão de mundo autoral e o universo axiológico vigente no texto, ou seja, o conjunto de valores que fundamentam as opções até mesmo vocabulares presentes na representação" (p. 34). Além disso, faz-se necessária a assunção de uma perspectiva relacionada à história e cultura dos negros e afrodescendentes - uma "perspectiva afroidentificada" (p. 37).

Em relação à linguagem, o autor afirma: "a afro-brasilidade tornar-se-á visível também a partir de um vocabulário pertencente às práticas linguísticas oriundas de Àfrica e inseridas no processo transculturador em curso no Brasil. Ou de uma discursividade que ressalta ritmos, entonações e, mesmo, toda uma semântica própria, empenhada muitas vezes num trabalho de ressignificação que contraria sentidos hegemônicos da língua" (p. 38).

Finalmente, em relação ao público, o autor destaca a necessidade da formação de um "horizonte recepcional afrodescendente" (p. 41), distinguindo, também por esse aspecto, a literatura afro-brasileira da literatura brasileira em geral. Trata-se de um público marcado pelo anseio de uma afirmação identitária, que, no limite, pode levar, inclusive, a outros espaços mediadores entre o texto e o leitor (como os saraus periféricos, a encenação teatral, as rodas de poesia etc.).

Como conclusão, o autor lembra que estes cinco componentes atuam como constantes discursivas presentes em textos e épocas diferentes, assumindo a condição de critérios 
diferenciadores da produção literária afro-brasileira, devendo, por fim, ser considerados não isoladamente, mas em sua inter-relação. A literatura afro-brasileira, portanto, estaria situada dentro e fora da literatura brasileira: "Uma produção que está dentro porque se utiliza da mesma língua e, praticamente, das mesmas formas e processos de expressão. Mas que está fora porque, entre outros fatores, não se enquadra no ideal romântico de instituir o advento do espírito nacional" (p. 43). Trata-se, assim, de um projeto suplementar ao da literatura brasileira canônica: "o de edificar uma escritura que seja não apenas a expressão dos afrodescendentes enquanto agentes de cultura e de arte, mas que aponte o etnocentrismo que os exclui do mundo das letras e da própria civilização. Daí seu caráter muitas vezes marginal, porque fundado na diferença que questiona e abala a trajetória progressiva e linear de nossa história literária" (p. 43).

A segunda parte da obra é um extenso guia de autores e obras da literatura afrobrasileira. Há ainda, finalmente, um artigo de Abdias Nascimento, intitulado "A cultura africana na arte brasileira", publicado originalmente na década de 1970, nos Estados Unidos.

No segundo volume, o autor volta-se especificamente para o trabalho com a literatura afro-brasileira na sala de aula, procurando assim incidir diretamente "nos processos de educação literária e de formação do hábito de leitura" (p. 09). O livro divide-se em três segmentos, para os quais concorre a colaboração de várias pesquisadoras: o primeiro, traçando um paronama da literatura afro-brasileira voltada a crianças e jovens; o segundo, contendo oito sequências didáticas destinadas ao Ensino Fundamental; e o terceiro, composto por doze sequências didáticas para o Ensino Médio.

Ambos os livros - que, de certo modo, complementam sua obra anterior, de maior fôlego: Literatura e afrodescendência no Brasil (2011), em quatro volumes - merecem ser conhecidos não apenas por quem busca conhecer um pouco mais da produção literária afrobrasileira, mas também por quem busca uma perspectiva crítica do assunto, bem como sugestões para uma prática pedagógica centrada nele.

\section{Recebido em 22/05/16 - Aprovado em 06/07/16}

